\title{
The anti-catabolic efficacy of insulin-like growth factor-I is enhanced by its early administration to rats receiving dexamethasone
}

\author{
F M Tomas \\ Cooperative Research Centre for Tissue Growth and Repair, PO Box 10065, Gouger Street, Adelaide, South Australia 5000, Australia
}

\begin{abstract}
The anti-catabolic efficacy of IGF-I treatment commencing before, with or after the onset of catabolism was compared in order to test whether earlier treatment can more effectively blunt a catabolic response. Young rapidly growing male rats (145 g body weight) and old weightstable female rats $(270 \mathrm{~g}$ body weight) were used in two experiments. The IGF-I variant LR $^{3}$ IGF-I was continuously infused at $280 \mu \mathrm{g} /$ day from 2 days before (early), concurrent with or 2 days after (delayed) commencement of a 6 day dexamethasone infusion $(125 \mu \mathrm{g} / \mathrm{kg}$ per day).

Both early and delayed treatment of young rats with LR $^{3}$ IGF-I significantly reduced the measured catabolic effects of dexamethasone. Early treatment was more effective than delayed treatment, with significantly higher nitrogen balance $(90 \pm 12$ vs $31 \pm 6 \mathrm{mg} /$ day), carcass nitrogen gain $(0 \cdot 37 \pm 0 \cdot 27$ vs $-1 \cdot 13 \pm 0 \cdot 10 \%$ per day $)$ and protein fractional synthesis rates after $2(10 \cdot 4 \pm 0 \cdot 5 \mathrm{vs}$ $8.3 \pm 0.2 \%$ per day) and 6 days of dexamethasone $(8 \cdot 2 \pm 0 \cdot 6$ vs $7 \cdot 0 \pm 0 \cdot 3 \%$ per day). Similarly, fractional breakdown rates of carcass protein were maintained at
\end{abstract}

significantly lower levels in rats given early treatment $(6 \cdot 23 \pm 0 \cdot 24$ vs $6 \cdot 60 \pm 0 \cdot 22 \%$ per day). In contrast, the old rats were less responsive to $\mathrm{LR}^{3}$ IGF-I treatment and only early and concurrent treatment significantly reduced the catabolic response, partly because of higher food intake. Early treatment was superior to delayed treatment and led to significantly higher nitrogen balance $(-19 \pm 11$ vs $-83 \pm 7 \mathrm{mg} /$ day) and carcass nitrogen fractional gain $(-1 \cdot 19 \pm 0 \cdot 40$ vs $-2 \cdot 76 \pm 0 \cdot 37 \%$ per day $)$ as well as lower final rates of carcass protein fractional breakdown ( $3 \cdot 55 \pm 0 \cdot 15$ vs $3 \cdot 83 \pm 0 \cdot 07 \%$ per day).

These experiments show that early (prophylactic) treatment with IGF-I is superior to delayed treatment for reducing catabolism induced by dexamethasone. The results provide the basis for further research to determine if prophylactic IGF-I treatment is useful in other circumstances where catabolism can be anticipated, such as in elective major surgery.

Journal of Endocrinology (1998) 157, 89-97

\section{Introduction}

The catabolic response to major illness, injury or surgery has been extensively documented (e.g. Cuthbertson 1964, Batstone et al. 1974, Kinney 1976). Many studies have been directed to finding a means to minimise the loss of body nitrogen following severe trauma. These have largely focused on the use of nutritional support and/or hormonal therapies which commence some time after the onset of the catabolic response (reviewed by Ziegler et al. 1994). Hormones that have been examined include insulin, growth hormone, insulin-like growth factor-I (IGF-I) and anabolic steroids. Although each of these therapies can be effective, they only partially ameliorate the catabolism.

IGF-I can substantially reverse the catabolism induced by glucocorticoids in rats (Tomas et al. 1992) and humans (Mauras \& Beaufrere 1995). We found that, although IGF-I was effective whether given concurrently with the glucocorticoid (Tomas et al. 1992) or 2 days later (Tomas et al. 1991), the earlier treatment appeared to be more effective. Our data suggested that the IGFs were more effective at restricting the development and extent of the catabolic response than in reversing an established catabolism. This view is consistent with the data of Miller et al. (1994), who reported that treatment of rats with IGF-I commencing before an ischaemic renal insult resulted in improved recovery compared with the same treatment commencing $24 \mathrm{~h}$ after the injury. Similarly, Ogawa et al. (1996) reported that treatment with growth hormone before the start of fasting-induced catabolism in lambs was at least as effective at restricting the degree of catabolism as the same treatment given after the start of the catabolic event. These workers also reported that the degree of catabolism was inversely related to the level of circulating IGF-I, suggesting that the major action of growth hormone in this case was via stimulation of IGF-I production. Overall, these results suggest that early (prophylactic) 
treatment in cases such as elective surgery may be the most effective strategy to minimise net loss of tissue and the period of hospitalisation.

We have compared the effects of the timing of commencement of administration of an IGF-I variant, LR ${ }^{3}$ IGF-I, on protein turnover and balance in dexamethasone-treated rats. LR $^{3}$ IGF-I treatment was begun before, with or after the commencement of dexamethasone treatment. Earlier treatment is more effective for suppression of catabolism, particularly in young growing animals.

\section{Materials and Methods}

\section{Metabolic agents}

Recombinant human LR $^{3}$ IGF-I was obtained from GroPep Pty Ltd, Adelaide, SA, Australia. This IGF-I variant has arginine instead of glutamate at position 3 as well as an N-terminal extension peptide (Francis et al. 1992) and shows greatly reduced affinity for binding to IGF-binding proteins, especially in rats (Francis et al. 1992, Lord et al. 1994). The LR ${ }^{3}$ IGF-I was dissolved and diluted as required in $0.1 \mathrm{M}$ acetic acid and continuously infused into animals via Alzet model 2001 osmotic pumps (Alza, Palo Alto, CA, USA). Dexamethasone was obtained as the sodium phosphate salt (Dexadreson; Intervet, Boxmeer, The Netherlands) and diluted as required in $0.9 \% \mathrm{NaCl}$ solution. Dexamethasone was infused using a separate Alzet model 2001 osmotic pump at a concentration to deliver $125 \mu \mathrm{g}$ dexamethasone $/ \mathrm{kg}$ starting body weight per day to each rat.

\section{Experimental design}

Two experiments were performed. In the first, young male Hooded Wistar rats (aged 6 weeks, $135 \mathrm{~g}$ body weight; CSIRO Division of Human Nutrition) were individually housed in Techniplast metabolism cages at $25{ }^{\circ} \mathrm{C}$ with lighting controlled over a $12 \mathrm{~h}$ light: $12 \mathrm{~h}$ darkness cycle. They had continuous access to water and a high-carbohydrate diet which contained $180 \mathrm{~g}$ casein and $2.5 \mathrm{~g}$ methionine $/ \mathrm{kg}$ and which was free of $N^{\tau}$ methylhistidine ( $\mathrm{N}^{\tau}-\mathrm{MH}$; Tomas et al. 1984).

After several days of adaptation in the metabolism cages, daily quantitative collection of excreta and measurement of food intake and body weight was commenced and continued until the end of the experiment. Two days after the commencement of collections, the rats (average weight about $145 \mathrm{~g}$ ) were randomised into five treatment groups of five animals as follows: vehicle control, early LR ${ }^{3}$ IGF-I $(280 \mu \mathrm{g} /$ day $)$, dexamethasone $(20 \mu \mathrm{g} /$ day; $125 \mu \mathrm{g} / \mathrm{kg}$ starting body weight per day) control and dexamethasone with either early or delayed $L^{3}{ }^{3}$ IGF-I. The treatment protocol is summarised in Fig. 1. Infusion pumps were

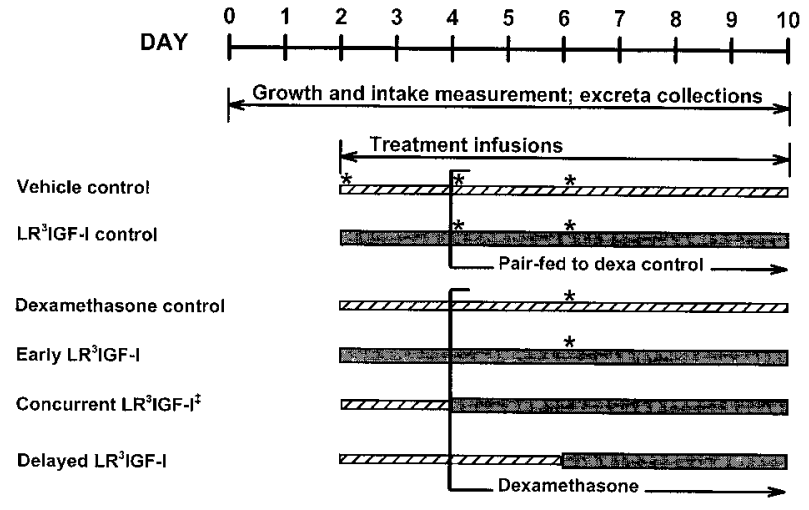

Figure 1 Treatment schedule for experimental groups over the 10 day experimental period. Hatched bars show periods of vehicle infusion and filled bars periods of LR ${ }^{3}$ IGF-I infusion ( $280 \mu \mathrm{g} /$ day). Dexamethasone was infused at $125 \mu \mathrm{g} / \mathrm{kg}$ body weight per day. Control groups without dexamethasone were pair-fed to the dexamethasone control group. Asterisks indicate extra groups of rats killed to obtain intermediate carcass composition and protein synthesis data. Only old rats received the concurrent LR ${ }^{3}$ IGF-I treatment.

inserted subcutaneously into the suprascapular region while the rats were under halothane anaesthesia. In order to estimate changes in body composition and to examine intermediate changes in protein turnover, additional groups of five rats were killed at the times indicated in Fig. 1.

At the end of the designated period of observation, each animal was lightly restrained in an open weave cloth and injected via a tail vein with $10 \mathrm{ml} / \mathrm{kg}$ of a solution containing $150 \mathrm{mM}$ phenylalanine and 1.48 MBq L-[2,6$\left.{ }^{3} \mathrm{H}\right]$ phenylalanine/ml. After $15 \mathrm{~min}$ the rats were stunned then immediately decapitated. Trunk blood was collected into a heparinised tube. One gastrocnemius muscle was rapidly removed and immediately frozen between aluminium blocks cooled in liquid $\mathrm{N}_{2}$. After removal of the pelt, viscera, feet and tail the remaining carcass was weighed and stored at $-20{ }^{\circ} \mathrm{C}$.

Young growing rats have a strong anabolic drive which is responsive to IGF-I (Hizuka et al. 1986, Tomas et al. 1993b), and the accelerated somatic growth may be a factor in the anti-catabolic effects of early LR $^{3}$ IGF-I treatment. Thus, the second experiment examined the effects of the above treatments in 'old' female rats which had reached stable mature body weight (20-21 weeks of age, $270 \mathrm{~g}$ body weight). The protocol used was essentially as described for experiment 1 . The dose of LR ${ }^{3}$ IGF-I was not altered $(280 \mu \mathrm{g} /$ day $)$ despite the larger body weight (about 1.6-fold higher fat-free mass) in order to further minimise promotion of somatic growth during the 2 days before dexamethasone infusion. Experiment 2 was performed in three stages, each with two animals per group.

The experimental protocols followed the Australian Code of Practice for the Care and Use of Animals for 
Scientific Purposes, and were approved by the Animal Experimentation Ethics Committee of the CSIRO Division of Human Nutrition.

\section{Analytical methods}

The nitrogen contents of food, faeces, urine and dried carcass were measured by the Dumas procedure with a Carlo Erba NA1500 Nitrogen Analyser (Milan, Italy). Urinary $\mathrm{N}^{\tau}-\mathrm{MH}$ was measured by continuous flow analysis (Tomas et al. 1991). The rationale and validity of the use of $\mathrm{N}^{\tau}-\mathrm{MH}$ excretion as an index of muscle protein has been discussed previously (Tomas \& Ballard 1987, Tomas et al. 1993a). The rate of muscle protein breakdown was calculated as the fractional excretion of the carcass $\mathrm{N}^{\tau}-\mathrm{MH}$ pool (\% per day), which largely reflects the rate of breakdown of the myofibrillar proteins. Muscle total RNA was measured as described by Munro \& Fleck (1969). Rates of muscle protein synthesis were determined essentially as described by Garlick et al. (1980) and expressed as a fractional rate $\left(k_{\mathrm{s}} ; \%\right.$ of protein pool synthesised per day) and as a rate per unit of RNA (g protein synthesised/g RNA per day). The rationale for the use of the 'flooding dose' method for measurement of protein synthesis has been presented elsewhere (Garlick et al. 1980, Reeds 1992). Average breakdown rates of total mixed muscle protein were calculated by subtracting average accretion rates of carcass protein from the average synthesis rates pooled from the different matched-treatment groups killed at various time points. The combining of pooled data from separate groups resulted in only a single estimate for each treatment which precluded statistical analysis.

\section{Statistics}

Values are presented as means \pm s.E.M. Significance of between-treatment effects was assessed by multiple regression analysis (Systat 5.0; Systat Inc, Evanston, IL, USA). In cases where the values were significantly related to either initial (starting) values or food intake, treatment effects were examined by analysis of covariance after homogeneity of slopes was established. Pair-fed groups were not included when food intake was used as a covariate because of restricted variance in food intake. Multiple comparisons with a chosen reference group were made using Dunnett's test or adjusted ' $t$ ' values according to the Bonferroni principle for multiple comparisons. Tukey's test was used for multiple comparisons amongst means. $P \leq 0.05$ was used as the level of significance.

\section{Results}

\section{Food intakes and body weight change}

Initial food intakes averaged over the 2 days before commencement of experimental treatments were $16 \cdot 2 \pm 0 \cdot 2$ and $17 \cdot 4 \pm 0 \cdot 6 \mathrm{~g} /$ day $(116 \cdot 2 \pm 1 \cdot 4$ and $65 \cdot 4 \pm 1 \cdot 8 \mathrm{~g} / \mathrm{kg}$ body weight per day) for young and old rats respectively. Dexamethasone treatment decreased food intakes to half of control levels on the second day of treatment. Young rats slowly increased intakes towards near-normal thereafter but the old rats showed a further reduction on the third day to only $10 \%$ of normal before slowly recovering to around half normal intake (data not shown). There was no significant difference in average food intake between the pair-fed controls and the dexamethasone control rats (Fig. $2 \mathrm{a}$ and $\mathrm{b}$ ). LR $^{3}$ IGF-I treatment maintained significantly higher food intakes in both young and old rats treated with dexamethasone (Fig. 2a and b), but when food intake was normalised to body weight this effect remained only for old rats $(24.6 \pm 2.4 \mathrm{~g} / \mathrm{kg}$ per day for dexamethasone controls vs $37 \cdot 9 \pm 4 \cdot 2,28 \cdot 3 \pm 1 \cdot 6$ and $34 \cdot 4 \pm 2 \cdot 2 \mathrm{~g} / \mathrm{kg}$ per day for early, concurrent and delayed LR $^{3}$ IGF-I treatment respectively). There were no significant differences in normalised food intake between the LR $^{3}$ IGF-I treatment groups.

In the young rats dexamethasone infusion caused an average body weight loss of $25.4 \pm 2.5 \mathrm{~g}$ while pair-fed controls gained up to $1.5 \mathrm{~g}$ per day (Fig. 2c). LR ${ }^{3}$ IGF-I infusion substantially reduced net weight loss to $4 \mathrm{~g}$, which is not significantly different from pair-fed vehicle controls. Early LR ${ }^{3}$ IGF-I treatment was not more effective than a delayed infusion. The old rats showed a different response pattern (Fig. 2d). Administration of dexamethasone caused a weight loss of $48 \pm 4 \mathrm{~g}$ but the fractional weight loss was about the same as for young rats $(17 \cdot 5 \%$ of body weight compared with $15 \cdot 8 \%$ ). The pair-fed controls also showed a substantial weight loss, about half of the dexamethasone effect, reflecting the much greater reduction in food intake after dexamethasone treatment in old rats. Only early and concurrent treatment with LR ${ }^{3}$ IGF-I significantly reduced the weight loss due to dexamethasone infusion but the effect of early treatment appears to be due to the better maintenance of food intake (Table 1).

\section{Whole body and carcass nitrogen balance}

Nitrogen balances in young rats reflected the changes in body weight except that differences were more pronounced because of lower variability, and in the rats infused with dexamethasone there was a marked significant advantage to early treatment with LR $^{3}$ IGF-I compared with delayed treatment (Fig. 2e; Table 1). LR $^{3}$ IGF-I did not significantly promote carcass nitrogen gain in control pair-fed rats but halved the catabolic effect of dexamethasone (Fig. 2g). Early LR $^{3}$ IGF-I treatment was significantly more effective in this action than delayed LR ${ }^{3}$ IGF-I treatment, which did not prevent net loss of nitrogen from the carcass (Fig. 2g; Table 1). Carcass nitrogen gain/loss over all treatments was linearly related to the nitrogen balance (Nbal; $r^{2}=0.90, \quad P<0 \cdot 001$ ) 
Young rats

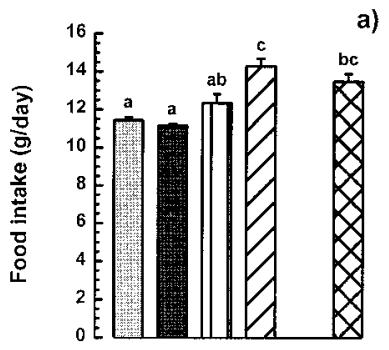

a)
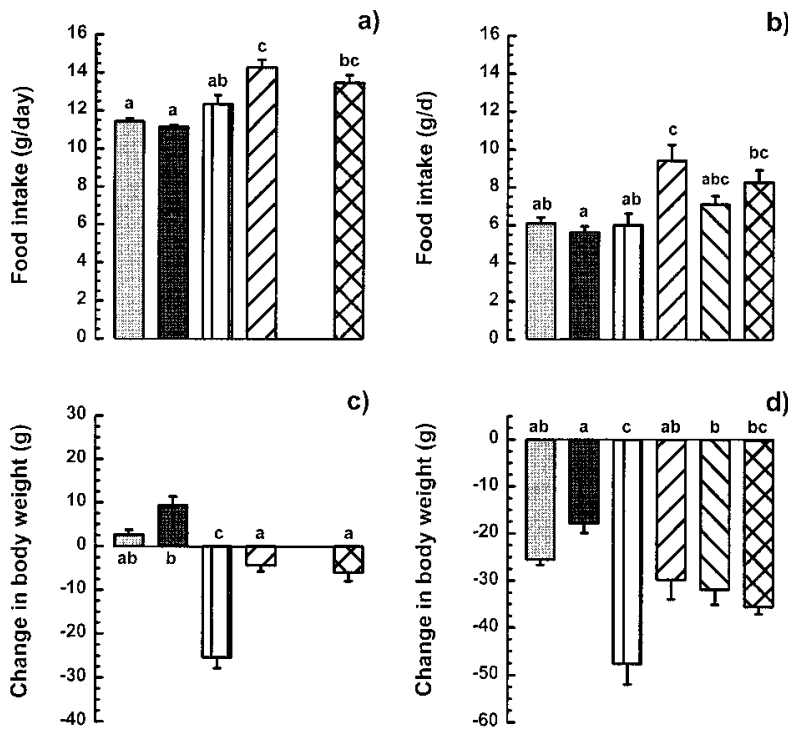

c)
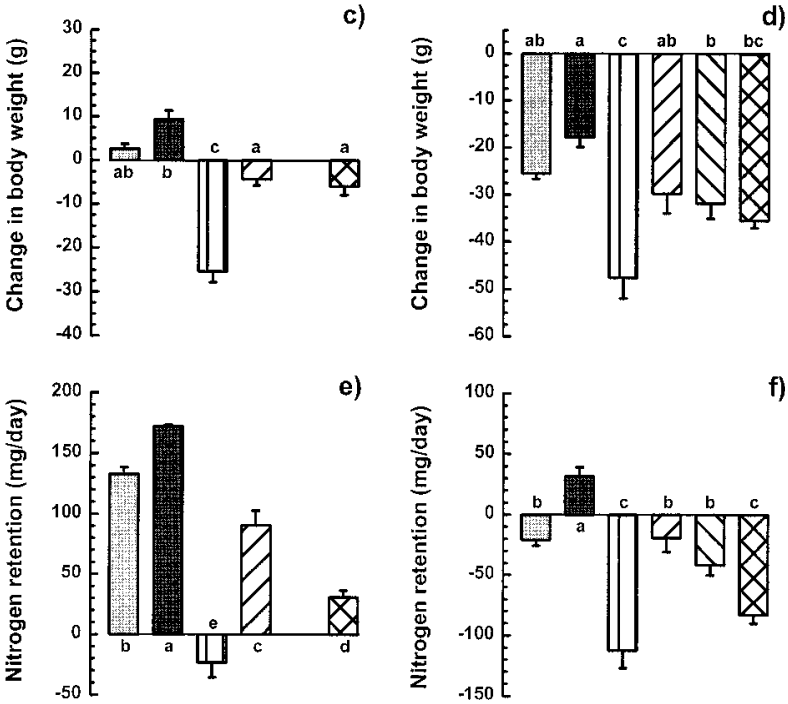

g)
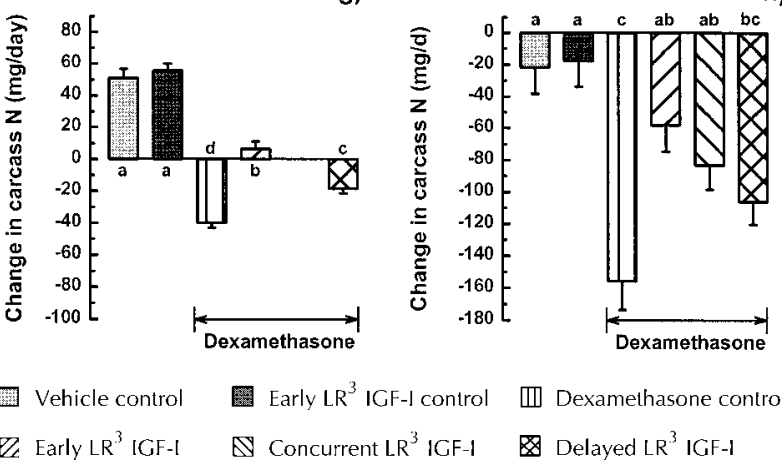

Figure 2 Average food intake $(a, b)$, change in body weight (c, d), nitrogen retention $(\mathrm{e}, \mathrm{f})$ and the change in carcass nitrogen content $(\mathrm{g}, \mathrm{h})$ for young and old rats. Vehicle control, early LR ${ }^{3}$ IGF-I control, dexamethasone control, early LR ${ }^{3}$ IGF-I, concurrent LR ${ }^{3}$ IGF-I and delayed LR ${ }^{3}$ IGF-I treatments are defined in Fig. 1. All data are integrated over the 6 day period of dexamethasone infusion. Bars show mean \pm S.E.M. for five (young) or six (old) rats per group. For bars not bearing common letters, the means are significantly different (Tukey's test; $P<0 \cdot 05$ ).

and accounted for half of the changes in nitrogen retention values (delta carcass nitrogen $=0.507( \pm 0.036) \times$ Nbal $-29 \cdot 8( \pm 3 \cdot 9) ; P<0 \cdot 001)$.
Nitrogen balances were much lower in the old rats but the response patterns in whole body and carcass were similar to that seen in young growing rats. Only early and concurrent treatment with LR $^{3}$ IGF-I significantly reduced the nitrogen losses caused by dexamethasone (Fig. 2f and h; Table 1). The delayed treatment did not significantly reduce nitrogen loss. Regression analysis showed a significant relationship between nitrogen balance and the relative time of starting LR $^{3}$ IGF-I treatment (start time $=-2,0,+2$ days) for the three comparable groups receiving both dexamethasone and $\mathrm{LR}^{3} \mathrm{IGF}-\mathrm{I}(\mathrm{Nbal}(\mathrm{mg} /$ day $)=-16 \cdot 0( \pm 3 \cdot 2) \times$ start time $-47 \cdot 7( \pm 5 \cdot 3) ; r^{2}=0 \cdot 60$, $P<0 \cdot 001)$. There was a similar relationship between the loss of nitrogen from the carcass $(P<0 \cdot 05)$ and the relative time of starting LR $^{3}$ IGF-I treatment. Statistical adjustment for the possible effect of food intake draws together the responses to early and concurrent treatments but the statistical comparisons amongst means is virtually unchanged (Table 1; Fig. 2). As was found with the young rats, the changes in carcass nitrogen were linearly related to the nitrogen balance $\left(r^{2}=0.53, P<0 \cdot 001\right)$ but in this case accounted for $86 \%$ of the change in nitrogen retention (delta carcass nitrogen $=0.86( \pm 0.14) \times$ $\mathrm{Nbal}-38 \cdot 7( \pm 9 \cdot 0) ; P<0 \cdot 001)$.

\section{Protein synthesis and degradation}

Compared with pair-fed controls, dexamethasone treatment significantly reduced protein synthesis rates in gastrocnemius muscle when measured at 2 and 6 days after treatment in both young and old rats (Fig. $3 \mathrm{a}$ and b). Early treatment with LR $^{3}$ IGF-I significantly attenuated the effect of dexamethasone at each of these time points in young rats and by the last day in the old rats. Later commencement of the LR ${ }^{3}$ IGF-I treatment did not significantly ameliorate the dexamethasone inhibition of protein synthesis rates.

In young rats both the tissue RNA content (data not shown) and the rate of protein synthesis per unit RNA $\left(K_{\mathrm{RNA}}\right.$; Fig. 3c) were reduced by dexamethasone. Early LR $^{3}$ IGF-I treatment largely prevented this fall in efficiency of RNA use for protein synthesis. In contrast, $\mathrm{LR}^{3}$ IGF-I did not attenuate the fall in $K_{\mathrm{RNA}}$ in old rats (Fig. 3d).

Changes in carcass protein accretion can be a result of changes in protein synthesis rates or breakdown rates, or both. The average rate of carcass muscle protein breakdown as calculated from the rate of $\mathrm{N}^{\tau}-\mathrm{MH}$ excretion was increased by around 1.7 -fold by dexamethasone treatment in both experiments (Table 2). In young rats, LR $^{3}$ IGF-I treatment suppressed this increase but there was no significant advantage to early treatment. The $\mathrm{N}^{\tau}-\mathrm{MH}-$ based data, which primarily relate to the myofibrillar proteins, are in general agreement with the breakdown rates of total mixed proteins calculated independently as the difference between the rates of synthesis and accretion. 
Table 1 Changes in body weight, carcass nitrogen content and nitrogen balance in young male (145 g) and old female (270 g) rats infused for 6 days with dexamethasone and treated with LR ${ }^{3}$ IGF-I $(280 \mu \mathrm{g} /$ day $)$

Treatment

\begin{tabular}{|c|c|c|c|c|}
\hline Vehicle & $\begin{array}{l}\text { Early } \\
\text { LR }^{3} \text { IGF-I }\end{array}$ & $\begin{array}{l}\text { Concurrent } \\
\text { LR }^{3} \text { IGF-I }\end{array}$ & $\begin{array}{l}\text { Delayed } \\
\text { LR }^{3} \text { IGF-I }\end{array}$ & $S E_{\text {Diff }} \dagger$ \\
\hline $\begin{array}{r}-21 \cdot 6^{a} \\
-9 \cdot 3^{a} \\
-36 \cdot 2^{a}\end{array}$ & $\begin{array}{r}-5 \cdot 2^{\mathrm{b}} \\
+77 \cdot 2^{\mathrm{c}} \\
+3 \cdot 1^{\mathrm{c}}\end{array}$ & - & $\begin{array}{r}-3 \cdot 2^{b} \\
+29 \cdot 8^{b} \\
-18 \cdot 6^{b}\end{array}$ & $\begin{array}{c}2 \cdot 40 \\
11 \cdot 4 \\
4 \cdot 80\end{array}$ \\
\hline $\begin{array}{r}-41 \cdot 0^{a} \\
-97 \cdot 7^{a} \\
-137 \cdot 8^{a}\end{array}$ & $\begin{array}{l}-36 \cdot 4^{\mathrm{ab}} \\
-33 \cdot 8^{\mathrm{b}} \\
-76 \cdot 9^{\mathrm{b}}\end{array}$ & $\begin{array}{l}-29 \cdot 5^{b} \\
-36 \cdot 2^{b} \\
-76 \cdot 8^{b}\end{array}$ & $\begin{array}{c}-37 \cdot 8^{\mathrm{ab}} \\
-87 \cdot 8^{\mathrm{a}} \\
-112 \cdot 5^{\mathrm{ab}}\end{array}$ & $\begin{array}{l}2 \cdot 94 \\
10 \cdot 7 \\
20 \cdot 7\end{array}$ \\
\hline
\end{tabular}

LR ${ }^{3}$ IGF-I infusion started 2 days before (early), at the same time (concurrent) or 2 days after (delayed) dexamethasone infusion. Values are means adjusted by covariance analysis for the apparent effect of food intake. Means in rows not sharing a common superscript are significantly different $(P<0 \cdot 05)$.

* Response not significantly related to food intake.

tCalculated from ANOVA error mean square.

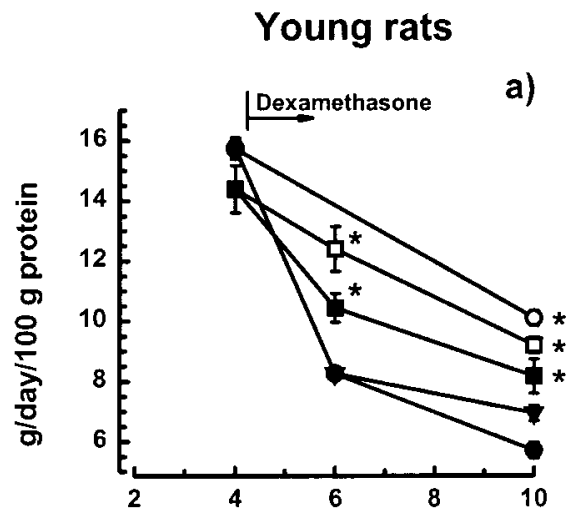

Old rats

Experiment

Young rats

$(n=5)$

Old rats

$(n=6)$
Body weight (g)

$\mathrm{N}$ balance (mg/day)

Carcass N (mg/day)

\section{$\mathrm{N}$ balance $(\mathrm{mg} / \text { day })^{*}$ \\ Carcass N (mg/day)*}

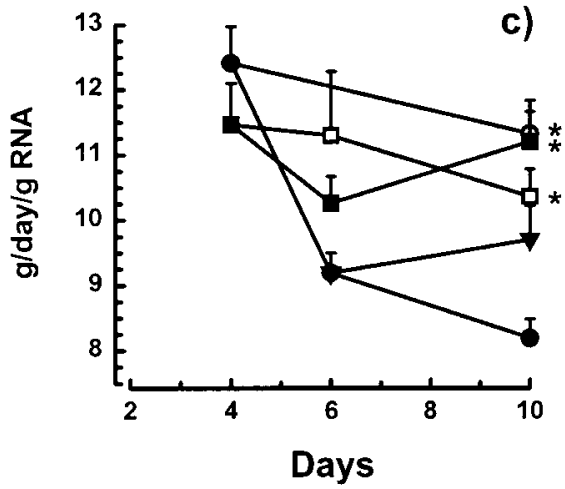

c)

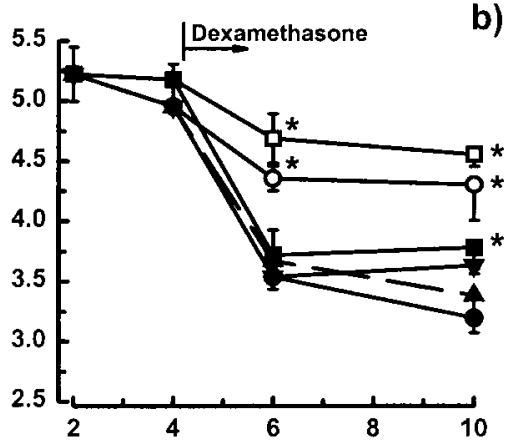

b)

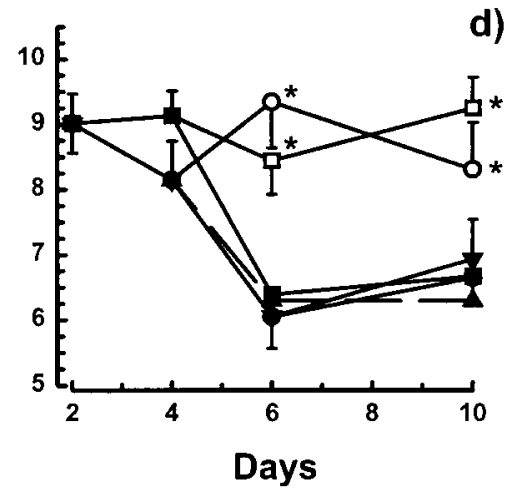

d)

Figure 3 Muscle protein fractional synthesis rates expressed as a fraction of protein mass $(a, b)$ and per unit RNA content (c, d) for young and old rats. Vehicle control $(O)$, early LR IGF-I control $(\square)$, dexamethasone control $(\bullet)$ early LR IGF-I ( $\mathbf{\square})$, concurrent LR ${ }^{3}$ IGF-I $(\boldsymbol{\Delta})$ and delayed LR ${ }^{3}$ IGF-I $(\boldsymbol{\nabla})$ treatments are defined in Fig. 1. Observations before the final day were obtained from separate groups of similarly treated rats. Each point shows the mean \pm S.E.M. for five (young) or six (old) rats. Means with asterisks are significantly different from the group receiving dexamethasone alone (Tukey's test; $P<0 \cdot 05$ ). 
Table 2 Fractional protein turnover rates in carcass muscle of young male (145 g) and old female ( 270 g) rats infused for 6 days with dexamethasone and treated with LR $^{3}$ IGF-I $(280 \mu \mathrm{g} /$ day $)$. Values are mean \pm S.E.M.

Experimental treatment

\begin{tabular}{|c|c|c|c|c|c|}
\hline \multirow[b]{2}{*}{$\begin{array}{l}\text { Pair-fed* } \\
\text { vehicle }\end{array}$} & \multirow[b]{2}{*}{$\begin{array}{l}\text { Pair-fed* } \\
\text { LR }^{3} \text { IGF-I }\end{array}$} & \multicolumn{4}{|c|}{ Dexamethasone infusion ( $125 \mu \mathrm{g} / \mathrm{kg}$ per day) } \\
\hline & & Vehicle & $\begin{array}{l}\text { Early } \\
\text { LR }^{3} \text { IGF-I }\end{array}$ & $\begin{array}{l}\text { Concurrent } \\
\text { LR }^{3} \text { IGF-I }\end{array}$ & $\begin{array}{l}\text { Delayed } \\
\text { LR IGF-I }\end{array}$ \\
\hline $2 \cdot 76 \pm 0 \cdot 31^{\mathrm{a}}$ & $3 \cdot 10 \pm 0 \cdot 23^{\mathrm{a}}$ & $-2 \cdot 5 \pm 0 \cdot 24^{\mathrm{d}}$ & $0 \cdot 37 \pm 0 \cdot 27^{b}$ & - & $-1 \cdot 13 \pm 0 \cdot 19^{c}$ \\
\hline $4 \cdot 08 \pm 0 \cdot 07^{\mathrm{a}}$ & $5 \cdot 02 \pm 0 \cdot 15^{b}$ & $7 \cdot 53 \pm 0 \cdot 24^{d}$ & $6 \cdot 23 \pm 0 \cdot 24^{\mathrm{c}}$ & - & $6 \cdot 60 \pm 0 \cdot 22^{\mathrm{c}}$ \\
\hline $12 \cdot 91$ & $11 \cdot 66$ & $8 \cdot 65$ & $10 \cdot 34$ & - & $9 \cdot 06$ \\
\hline $10 \cdot 15$ & $8 \cdot 56$ & $11 \cdot 13$ & $9 \cdot 97$ & - & $10 \cdot 19$ \\
\hline$-0.72 \pm 0 \cdot 40^{\mathrm{ab}}$ & $-0 \cdot 41 \pm 0 \cdot 36^{a}$ & $-4 \cdot 32 \pm 0.43^{d}$ & $-1 \cdot 19 \pm 0 \cdot 40^{\mathrm{ab}}$ & $-2 \cdot 08 \pm 0 \cdot 30^{\mathrm{bc}}$ & $-2 \cdot 76 \pm 0 \cdot 37^{\mathrm{cd}}$ \\
\hline $2 \cdot 19 \pm 0 \cdot 04^{a}$ & $2 \cdot 21 \pm 0 \cdot 05^{a}$ & $3 \cdot 81 \pm 0 \cdot 12^{\mathrm{c}}$ & $3 \cdot 55 \pm 0 \cdot 15^{\mathrm{b}}$ & $3 \cdot 42 \pm 0 \cdot 08^{\mathrm{b}}$ & $3 \cdot 83 \pm 0 \cdot 07^{c}$ \\
\hline $4 \cdot 44$ & $4 \cdot 73$ & $3 \cdot 66$ & $3 \cdot 98$ & $3 \cdot 77$ & $3 \cdot 52$ \\
\hline $5 \cdot 16$ & $5 \cdot 14$ & $7 \cdot 98$ & $5 \cdot 17$ & $5 \cdot 86$ & $6 \cdot 28$ \\
\hline
\end{tabular}

LR ${ }^{3}$ IGF-I infusion was started 2 days before (early), at the same time (concurrent) or 2 days after (delayed) dexamethasone infusion. Values are expressed as percentage of protein pool accreted $\left(K_{\mathrm{A}}\right)$, degraded $\left(K_{\mathrm{D}}\right)$ or synthesised $\left(K_{\mathrm{S}}\right)$ per day. Means not sharing a common superscript are significantly different $(P<0 \cdot 05)$.

* Pair-fed to the dexamethasone+vehicle group. +Statistical differences calculated by covariance analysis to adjust for initial $\mathrm{N}^{\tau}$-MH excretion rates. Means shown are not adjusted. $K_{\mathrm{D}}\left(\mathrm{N}^{\tau}-\mathrm{MH}\right)$ is the estimated rate of (myofibrillar) protein breakdown based on $\mathrm{N} \tau$-methylhistidine. $K_{\mathrm{A}}, K_{\mathrm{D}}\left(K_{\mathrm{S}}-K_{\mathrm{A}}\right)$ and $K_{\mathrm{S}}\left({ }^{3} \mathrm{H}-\mathrm{Phe}\right)$ values were calculated as described in the text. $K_{S}\left(\left[{ }^{3} \mathrm{H}\right] \mathrm{Phe}\right)$ values are pooled averages of several measurements of the rate of $\left[{ }^{3} \mathrm{H}\right]$ phenylalanine incorporation obtained over the 6 day infusion period (see also Fig. 2). Since the pooled data were obtained from different groups of rats, no estimate of error could be made.

Thus the significantly higher rate of protein accretion observed with the earlier, rather than the delayed, start of LR $^{3}$ IGF-I treatment appears to be mostly due to the better maintained average protein synthesis rates, which were around 10\% higher for this treatment (see also Fig. $3 a)$. Older rats generally were less responsive and also showed a different response pattern, which for these measures was independent of the variation in food intake. Both early and concurrent treatment with LR $^{3}$ IGF-I significantly reduced the elevated rate of protein breakdown caused by dexamethasone infusion. However, the delayed treatment was ineffective and breakdown rates remained higher than those in the early treatment group (Table 2). Earlier starting of $\mathrm{LR}^{3}$ IGF-I treatment was also associated with the maintenance of higher average rates of protein synthesis and lower rates of total mixed protein breakdown throughout the treatment period (Table 2).

\section{Discussion}

Our data show that LR $^{3}$ IGF-I can more effectively counteract a catabolic response if treatment is commenced before the catabolism is established. The anti-catabolic effects of LR ${ }^{3}$ IGF-I presented here support and extend the earlier observations made by us and other workers with different animal models. Thus the anti-catabolic effects of IGF-I treatment have been well established in rats (Tomas et al. 1992, Lo et al. 1996), humans (Mauras \& Beaufrere 1995), and other species (Douglas et al. 1991). In addition, the superior efficacy of $\mathrm{LR}^{3}$ IGF-I and des(1-3)IGF-I for these actions has also been established using the rat (Tomas et al. 1992). However, in these earlier studies, the IGF treatment was commenced at the same time as the catabolic stimulus or sometime afterwards. We now report the first systematic study of the most appropriate time of administering the IGF to maximise the anti-catabolic efficacy. This is especially important for minimising the duration of hospitalisation after major surgery.

Although our experiments with the young and old rats are not strictly comparable because of relative differences in their metabolic states and LR ${ }^{3}$ IGF-I dosage, the similarity of the experimental designs is sufficient to allow combined discussion of the results in most cases. Thus, while body weight changes were not influenced by the time of commencement of IGF treatment, in each experiment the nitrogen balance over the 6 days of dexamethasone treatment was substantially higher when the rats received early rather than delayed $\mathrm{LR}^{3}$ IGF-I. Although nitrogen balances for the early and concurrent treatment groups were not significantly different in the old rats, the trend was for higher balances with the earlier treatment. This is supported by the highly significant linear regression between nitrogen balance and the relative time of commencement of LR ${ }^{3}$ IGF-I infusion. The trend was less pronounced but still present after food intakes were taken into account. We did not include a concurrent LR $^{3}$ IGF-I treatment in our young rat experiment. However, in an earlier report (Tomas et al. 1992), for which the experimental protocol was the same as that used for the young 
rats here, the increment above control values due to concurrent $L^{3}{ }^{3}$ IGF-I treatment was $+76 \mathrm{mg} /$ day. This is intermediate between the average increments found for the early (+113 mg/day) and delayed treatment (+53 mg/ day) groups in the young rats reported here. These results are consistent with the data for the old rats and indicate an incremental decrease in nitrogen loss with the earlier start of $\mathrm{LR}^{3}$ IGF-I treatment.

Preferential wasting of muscle tissue is a key characteristic of the catabolic response to trauma (e.g. Kinney 1976, Kinney \& Elwyn 1983). In short-term studies measures of weight change and nitrogen balance are not good indices of changes in muscle mass since the nitrogen lost to the musculature may be incorporated into other tissues rather than excreted. In the young rats, changes in carcass nitrogen content accounted for around $50 \%$ of the changes in the total nitrogen balance. This is somewhat higher than expected since muscle protein comprises $40-45 \%$ of the total protein content of a 6 -week-old $(150 \mathrm{~g})$ rat (Cheek et al. 1965, F M Tomas, unpublished observations). In the old rats, however, around $85 \%$ of changes in nitrogen retention were accounted for by changes in carcass nitrogen content, a much higher fraction than in young rats. Thus, while the young rats lost protein from muscle at a slightly faster rate than from other tissues in response to dexamethasone treatment, the old rats showed much higher preferential loss of protein from the carcass relative to other tissues. Young rats of the age and weight used here are still undergoing a rapid increase in the muscle mass relative to body weight by both plastic and trophic growth processes (Chinn \& Hannon 1966, Miller 1969). This strong anabolic drive may have been a contributing factor to the prevention of a large preferential loss of muscle tissue such as occurred in the mature females.

The difference in the relative anabolic state of the young and old rats is illustrated by their comparative rates of protein accretion and turnover in the gastrocnemius muscle (Fig. 3; Table 2). Muscle protein synthesis rates were around threefold higher and degradation rates twofold higher in the young rats, and the degree of responsiveness to treatment was much more pronounced. The more active state of protein metabolism and the associated responsiveness may explain the greater efficacy of LR $^{3}$ IGF-I in the young rats, although they did also receive a higher relative dose of the IGF. Notably, the LR $^{3}$ IGF-I did not affect the rate of protein synthesis per unit RNA in the old rats whereas in the young rats the ribosomal efficiency for protein synthesis was either held at nearnormal levels by early LR ${ }^{3}$ IGF-I treatment or returned towards normal by delayed treatment. Our earlier studies led us to suggest that the reduction of elevated protein breakdown rates appears to be a key mechanism by which concurrently administered IGF acts to ameliorate catabolism in a number of animal models (Tomas et al. 1993a). We note that in this study early treatment with IGF also allowed substantial modulation of the effect of dexametha- sone on muscle protein synthesis, particularly in young rats. Nonetheless, for both young and old rats, LR ${ }^{3}$ IGF-I did cause a significant reduction in breakdown rates, although this was restricted to the early treatment in old rats. The lower efficacy in the old rats may have been due to the lower dose of LR ${ }^{3}$ IGF-I infused. However, in young rats treated with dexamethasone, $\mathrm{N}^{\tau}-\mathrm{MH}$ was shown to be significantly reduced by LR $^{3}$ IGF-I at doses of $112 \mu \mathrm{g} / \mathrm{rat}$ per day $(0.75 \mathrm{mg} / \mathrm{kg}$ per day; Tomas et al. 1992), 2.5-fold less than the young rats in this report. The old rats in the current study received around $1.0 \mathrm{mg}$ LR $^{3}$ IGF-I/kg per day, about 1.3-fold higher than the effective dose cited above for young rats. Indeed, the dose was $1 \cdot 6$-fold higher on a lean body mass basis. Thus the differences between young and old rats are more likely to be due to a lower responsiveness of the musculature in these rats.

None of the dexamethasone-treated groups receiving LR ${ }^{3}$ IGF-I were pair-fed to the dexamethasone-treated controls since we did not expect these groups to show a smaller fall in average food intake. We cannot explain this response. It may be related to differential modulation of endogenous hormones, such as insulin, by the infused hormones. In the young rats, food intake per unit body weight did not vary between dexamethasone-treated groups, and differences due to LR ${ }^{3}$ IGF-I treatment could not simply be ascribed to effects on food intake (Table 1). This was not the case with the old rats, in which the ability of LR ${ }^{3}$ IGF-I to counteract the effects of dexamethasone may be partly explained by the differences in average food intake. Nonetheless, the statistical differences between treatments remained essentially unchanged when the data were analysed with food intake as a covariate (Table 1; Fig. 2d, $f$ and $h$ ), although the apparent trend favouring prophylaxis is largely lost. However, the variability in food intakes was high, particularly in the early treatment group. In addition, the correlation between a measured response and food intake within the small treatment groups was often very low or absent. This suggests that the adjusted means should also be interpreted with care. Notwithstanding the apparent influence of food intake, we note that LR $^{3}$ IGF-I treatment does not alter the relative contribution of muscle to the total nitrogen loss. This proportion appears to be primarily determined by dexamethasone treatment and the age of the rat.

The old rats in the LR ${ }^{3}$ IGF-I control group which were pair-fed to dexamethasone-treated controls maintained consistently higher rates of muscle protein synthesis than the untreated pair-fed controls (see Fig. 3, Table 2), indicating that the muscle was in a more anabolic state. This suggests that the level of anabolic activity at the commencement of a catabolic event may be an important determinant of the subsequent degree of catabolism. This view is consistent with the differences in catabolic severity and responsiveness observed between the young and old rats. It is also consistent with the improved postoperative 
protein metabolism in surgical patients who receive extra nutritional support before surgery (Ward et al. 1983).

Limiting the postoperative trauma response in patients after major elective surgery is one obvious application of early IGF treatment. The enhanced anti-catabolic outcome with early IGF-I treatment may also allow the use of lower doses of IGF-I, which could minimise the suppression of growth hormone and insulin secretion (e.g. Oehri et al. 1996) and development of clinical side effects (Jabri et al. 1994, Thompson et al. 1995). A recent report by Butterfield et al. (1997) has shown that IGF treatment in old women had anabolic effects on whole body and muscle protein synthesis rates consistent with our observations in the old-rat model. This consistent anabolic effect indicates the need for further studies to determine whether major surgery or other predictable trauma, which lead to a catabolic response in humans, may also be more effectively countered by the prophylactic administration of IGF-I.

\section{Acknowledgements}

We wish to thank Colin Chandler, Judith Burgoyne, Paul Rogers, Kerry Wright and Abrona Chappell for their skilful performance of the animal trials and subsequent assays.

\section{References}

Batstone GF, Alberti KG, Hinks L, Smythe P, Laing JE, Ward CM, Ely DW \& Bloom SR 1975 Metabolic studies in subjects following thermal injury. Intermediary metabolites, hormones and tissue oxygenation. Burns 2 207-225.

Butterfield GE, Thompson J, Rennie MJ, Marcus R, Hintz RL \& Hoffman AR 1997 Effect of rhGH and rhIGF-I treatment on protein utilization in elderly women. American Journal of Physiology 272 E94-E99.

Cheek DB, Powell GK \& Scott RE 1965 Growth of muscle mass and skeletal collagen in the rat. I. Normal growth. Bulletin of the Johns Hopkins Hospital 116 378-387.

Chinn KSK \& Hannon JP 1966 Relationship of muscle protein to other components of the fat free mass. American Journal of Physiology 211 993-997.

Cuthbertson DP 1964 Physical injury and its effects on protein metabolism. In Mammalian Protein Metabolism, vol 2, pp 373-414. Eds HN Munro \& JB Allison. New York: Academic Press.

Douglas RG, Gluckman PD, Breier BH, McCall JL, Parry B \& Shaw JH 1991 Effects of recombinant IGF-I on protein and glucose metabolism in rTNF-infused lambs. American Journal of Physiology 261 E606-E612.

Francis GL, Ross M, Ballard FJ, Milner SJ, Senn C, McNeill KA, Wallace JC, King R \& Wells JRE 1992 Novel recombinant fusion protein variants of insulin-like growth factor (IGF)-I indicate the relative importance of IGF-binding protein and receptor binding for enhanced biological potency. Journal of Molecular Endocrinology $\mathbf{8}$ 213-223.

Garlick PJ, McNurlan MA \& Preedy VR 1980 A rapid and convenient technique for measuring the rate of protein synthesis in tissues by injection of $\left[{ }^{3} \mathrm{H}\right]$ phenylalanine. Biochemical Journal 192 719-723.
Hizuka N, Takano K, Shizume K, Asakawa K, Miyakawa M, Tanaka I \& Horikawa R 1986 Insulin-like growth factor-I stimulates growth in normal growing rats. European Journal of Pharmacology 125 143-146.

Jabri N, Schalch DS, Schwartz SL, Fischer JS, Kipnes MS, Radnik BJ, Turman NJ, Marcsisin VS \& Guler H-P. 1994 Adverse effects of recombinant human insulin-like growth factor I in obese insulinresistant type-II diabetic patients. Diabetes 43 369-374.

Kinney JM 1976 Surgical hypermetabolism and nitrogen metabolism. In Metabolism and the Response to Injury, pp 237-252. Eds AW Wilkinson \& D Cuthbertson. Tunbridge Wells: Pitman Medical.

Kinney JM \& Elwyn DH 1983 Protein metabolism and injury. Annual Review of Nutrition 3 433-466.

Lo HC, Hinton PS, Yang H, Unterman TG \& Ney DM 1996 Insulin-like growth factor-I but not growth hormone attenuates dexamethasone-induced catabolism in parenterally fed rats. Journal of Parenteral and Enteral Nutrition 20 171-177.

Lord AD, Bastian SEP, Read LC, Walton PE \& Ballard FJ 1994 Differences in the association of insulin-like growth factor-I (IGF-I) and IGF-I variants with rat, sheep, pig, human and chicken plasmabinding proteins. Journal of Endocrinology 140 475-482.

Mauras N \& Beaufrere B 1995 Recombinant human insulin-like growth factor-I enhances whole body protein anabolism and significantly diminished the protein catabolic effects of prednisone in humans without a diabetogenic effect. Journal of Clinical Endocrinology and Metabolism 80 869-874.

Miller SA 1969 Protein metabolism during growth and development. In Mammalian Protein Metabolism, vol 3, pp 183-233. Eds HN Munro \& JB Allison. New York: Academic Press.

Miller SB, Martin DR, Kissane J \& Hammerman MR 1994 Rat models for clinical use of insulin-like growth factor I in acute renal failure. American Journal of Physiology 266 F949-F956.

Munro HN \& Fleck A 1969 Analysis of tissues and body fluids for nitrogenous constituents. In Mammalian Protein Metabolism, vol 3, pp 423-525. Eds HN Munro \& JB Allison. New York: Academic Press.

Oehri M, Ninnis R, Girard J, Frey FJ \& Keller U 1996 Effects of growth hormone and IGF-I on glucocorticoid-induced protein catabolism in humans. American Journal of Physiology $\mathbf{2 7 0}$ E552-E558.

Ogawa I, Breier BH, Bauer MK, Gallaher BW, Grant PA, Walton PE, Owens JA \& Gluckman PD 1996 Early treatment with bovine growth hormone is as effective as treatment during metabolic stress to reduce catabolism in fasted lambs. Endocrinology 137 1242-1248.

Reeds PJ 1992 Isotopic estimation of protein synthesis and proteolysis in vivo. In Modern Methods in Protein Nutrition and Metabolism, pp 249-273. Ed S Nissen. San Diego: Academic Press.

Thompson JL, Butterfield GE, Marcus R, Hintz RL, Van Loan M, Gihron L \& Hoffman AR 1995 The effects of recombinant human insulin like growth factor-I and growth hormone on body composition in elderly women. Journal of Clinical Endocrinology and Metabolism 80 1845-1852.

Tomas FM \& Ballard FJ 1987 Applications of the 3-methylhistidine technique for measuring myofibrillar protein breakdown in vivo. In Lysosomes: Their Role in Protein Breakdown, pp. 679-711. Eds H Glaumann \& FJ Ballard. London: Academic Press.

Tomas FM, Murray AJ \& Jones LM 1984 Modification of glucocorticoid-induced changes in myofibrillar protein turnover in rats by protein and energy deficiency as assessed by urinary excretion of $\mathrm{N}^{\tau}$-methylhistidine. British Journal of Nutrition $\mathbf{5 1}$ 323-337.

Tomas FM, Chandler CS, Knowles SE \& Ballard FJ 1991 Reversal of dexamethasone-induced catabolism in rats by insulin-like growth factor-I (IGF-I) and especially des(1-3)IGF-I. Proceedings of the Nutrition Society of Australia 16135.

Tomas FM, Knowles SE, Owens PC, Chandler CS, Francis GL, Read LC \& Ballard FJ 1992 Insulin-like growth factor-I (IGF-I) and 
especially IGF-I variants are anabolic in dexamethasone-treated rats. Biochemical Journal 282 91-97.

Tomas FM, Chandler CS, Knowles SE, Francis GL, Martin AA, Lemmey AB, Read LC \& Ballard FJ 1993a Muscle protein turnover and IGF-I: anticatabolic and anabolic effects of IGFs. In Proteolysis and Protein Turnover, pp 141-148. Eds AJ Barrett \& JS Bond. London: Portland Press.

Tomas FM, Knowles SE, Chandler CS, Francis GL, Owens PC \& Ballard FJ 1993b Anabolic effects of insulin-like growth factor-I (IGF-I) and an IGF-I variant in normal female rats. Journal of Endocrinology 137 413-421.
Ward MWN, Halliday D, Matthews DE, Matthews SM, Peters JL, Harrison RA, Clark CG \& Rennie MJ 1983 The effect of enteral nutritional support on skeletal muscle protein synthesis and wholebody protein turnover in fasted surgical patients. Human Nutrition: Clinical Nutrition 37C 453-458.

Ziegler TR, Gatsen C \& Wilmore DW 1994 Strategies for attenuating protein catabolic responses in the critically ill. Annual Reviews of Medicine 45 459-480.

Received 17 June 1997

Accepted 7 November 1997 